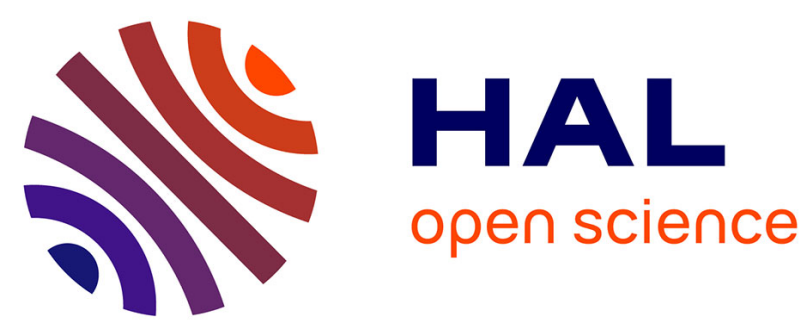

\title{
New Perspectives on Land-Atmosphere Feedbacks from the African Monsoon Multidisciplinary Analysis (AMMA)
}

Christopher M. Taylor, Douglas J. Parker, Norbert Kalthoff, Miguel Angel Gaertner, Nathalie Philippon, Sophie Bastin, Phil P. Harris, Aaron Boone, Françoise Guichard, Anna Agusti-Panareda, et al.

\section{To cite this version:}

Christopher M. Taylor, Douglas J. Parker, Norbert Kalthoff, Miguel Angel Gaertner, Nathalie Philippon, et al.. New Perspectives on Land-Atmosphere Feedbacks from the African Monsoon Multidisciplinary Analysis (AMMA). Atmospheric Science Letters, 2011, 12 (1), pp.38-44. 10.1002/asl.336 .

hal-00546971

\section{HAL Id: hal-00546971 \\ https://hal.science/hal-00546971}

Submitted on 30 Nov 2016

HAL is a multi-disciplinary open access archive for the deposit and dissemination of scientific research documents, whether they are published or not. The documents may come from teaching and research institutions in France or abroad, or from public or private research centers.
L'archive ouverte pluridisciplinaire HAL, est destinée au dépôt et à la diffusion de documents scientifiques de niveau recherche, publiés ou non, émanant des établissements d'enseignement et de recherche français ou étrangers, des laboratoires publics ou privés. 


\title{
New perspectives on land-atmosphere feedbacks from the African Monsoon Multidisciplinary Analysis
}

\author{
Christopher M. Taylor, ${ }^{*}$ Douglas J. Parker, ${ }^{2}$ Norbert Kalthoff,, Miguel Angel Gaertner, ${ }^{4}$ Nathalie Philippon, ${ }^{5}$ \\ Sophie Bastin, ${ }^{6}$ Phil P. Harris,' Aaron Boone,' Françoise Guichard, ${ }^{7}$ Anna Agusti-Panareda, ${ }^{8}$ Marina Baldi, \\ Paolina Cerlini, ${ }^{10}$ Luc Descroix, ${ }^{1}$ Hervé Douville, ${ }^{7}$ Cyrille Flamant, ${ }^{6}$ Jean-Yves Grandpeix ${ }^{12}$ and Jan Polcher, ${ }^{12}$ \\ 'Centre for Ecology and Hydrology, Wallingford, Oxfordshire, OXIO 8BB, UK \\ ${ }^{2}$ School of Earth and Environment, University of Leeds, Leeds, UK \\ ${ }^{3}$ Institute for Meteorology and Climate Research, Karlsruhe Institute of Technology, Hermann-von-Helmholtz-Platz I, D-76344 \\ Eggenstein-Leopoldshafen, Germany \\ ${ }^{4}$ Environmental Sciences Faculty, University of Castilla-La Mancha, Toledo, Spain \\ ${ }^{5}$ University of Bourgogne, Dijon, France \\ ${ }^{6}$ CNRS/INSU, LATMOS/IPSL, UPMC, Paris, France \\ ${ }^{7}$ CNRM (CNRS and Météo-France), Toulouse, France \\ ${ }^{8}$ European Centre for Medium-Range Weather Forecasts, Reading, UK \\ ${ }^{9}$ Institute of Biometeorology, Ibimet-CNR, Via Taurini 19, 00185 Rome, Italy \\ ${ }^{10} \mathrm{CRC/UniPg,} \mathrm{I} \mathrm{Piazza} \mathrm{Università,} \mathrm{Perugia,} \mathrm{Italy}$ \\ "IRD, Niamey, Niger \\ 12 LMD/IPSL, CNRS, Paris, France
}

*Correspondence to: Christopher M. Taylor, Centre for

Ecology and Hydrology,

Wallingford, Oxfordshire OX10

8BB, UK.

E-mail:cmt@ceh.ac.uk

Received: 9 February 2010

Revised: 9 December 2010

Accepted: 10 February 2011

\begin{abstract}
Research into land-atmosphere coupling within the African Monsoon Multidisciplinary Analysis has highlighted the atmospheric impact of soil moisture on space scales of $5 \mathbf{~ k m}$ upwards and time scales of several days. Observational and modelling studies have shown how antecedent rainfall patterns affect new storms in the Sahel. The land feedback operates through various mechanisms, including a direct link to afternoon storm initiation from surface-induced mesoscale circulations, and indirectly via a large-scale moisture transport in the nocturnal monsoon. The results suggest potential for significant improvements in weather forecasting through assimilation of satellite data. Intriguing questions remain about the importance of vegetation memory on seasonal-interannual scales. Copyright $(\subset) 2011$ Royal Meteorological Society
\end{abstract}

Keywords: soil moisture; convection; planetary boundary layer

\section{Introduction}

The West African Monsoon is considered to exhibit strong sensitivities to the land surface at a range of time and space scales. Studies using climate models by Charney (1975), Zeng et al.(1999) and Xue and Shukla (1993) amongst others have found feedbacks between vegetation cover and precipitation that may have contributed to the extreme Sahelian drought conditions in the 1970s and 1980s. On the annual time scale, there is some theoretical and observational evidence that pre-monsoon land surface conditions can affect rainfall in the wet season (Eltahir and Gong, 1996; Fontaine et al., 1999) via horizontal gradients in moist static energy. Observational and modelling studies have also shown how soil moisture can affect daily (Clark et al., 2004; Taylor and Lebel, 1998) and weekly (Koster et al., 2006) rainfall. The interest in West Africa as a globally important land-atmosphere 'hotspot' meant that land-atmosphere feedbacks provided an integrating focus within the African Monsoon Multidisciplinary Analysis (AMMA).
Prior to AMMA, there were a number of key unknowns relating to land-atmosphere interaction. Whilst there had been several observational campaigns in the region to measure the components of the surface energy balance (most notably HAPEX-Sahel), there was a lack of long-term data to evaluate land surface models across the monsoon region, ranging from the moist tropics in the south to the desert in the north, and incorporating a range of land uses. A study by Philippon and Fontaine (2002) had speculated that a memory of rainfall in the previous year in the Soudanian zone might affect the following Sahelian wet season, yet there was little observational insight into the length of such land 'memory'. Whilst observational studies had shown a marked response of the planetary boundary layer (PBL) to mesoscale soil moisture patterns (Taylor et al., 2003), it was unclear whether the surfacesensible heat flux gradients could drive significant daytime circulations, as predicted by models. If strong meso- and synoptic-scale circulations were induced by soil moisture, were they of any great relevance for understanding rainfall variability? For example were new storms initiated in mesoscale convergence zones, 
or at the larger scale, via changes in the strong nocturnal monsoon flow?

The strategy to answer these questions within the AMMA program involved taking new ground and atmospheric observations and combining them with remotely sensed data and numerical models. Key new results are summarised in this article, which concludes with a discussion of how the science should progress from here.

\section{Observations of surface and PBL response to rainfall}

The surface energy balance was monitored at sites which spanned a large range of climatic and land cover conditions found in West Africa, and the results are summarised by Seguis et al. (2011). Considering feedbacks on the atmosphere, Guichard et al. (2009) showed from observations in northern Mali how the seasonal evolution of the radiation balance couples with the surface thermodynamics in the Sahel. Of particular note is the marked increase in net radiation driven by the wet season transition from hot, sandy dunes to cooler, darker vegetated grasslands. Increased net radiation implies enhanced surface moist static energy, consistent with a positive soil moisture-rainfall feedback on the seasonal time scale. The response of the PBL to rainfall on shorter time scales was documented using a unique dataset collected from a wetter region in southern Burkina Faso (Kohler et al., 2010; Schwendike et al., 2010). These studies found strong responses in albedo, surface temperature and Bowen ratio for 2-3 days after a rain event, though once the seasonal vegetation cover was well established, the amplitude of the response weakened markedly. The PBL after the monsoon onset was typically half the value of its pre-onset height due to the weakening sensible heat flux. Throughout the campaign, the diurnal development of convective instability was dominated by changes in the PBL, and recovered within 2 days of the passage of a mesoscale convective system (MCS).

\section{Impact of surface variability on the PBL and moist convection}

To examine the impact of the above processes on the PBL at the mesoscale, an aircraft campaign was designed to target regions with strong spatial variations in surface fluxes, either from soil moisture or vegetation patterns. The example in Figure 1 (Taylor et al., 2007) illustrates the variability of near-surface soil moisture on scales up to $1000 \mathrm{~km}$ associated with the passage of MCS. Land surface models forced by observational estimates of precipitation in the AMMA Land Model Intercomparison Project (ALMIP, Boone et al., 2009) captured these large-scale upper-soil moisture structures (Figure 1(b)), unlike the ERA-Interim reanalysis product (Figure 1(c)). Assimilation of highresolution land surface temperature data into a land model (Figure 1(d); Harris and Taylor, manuscript in preparation) illustrates the substantial variability on spatial scales $\sim 10 \mathrm{~km}$ for which no reliable precipitation estimate exists.

The variations in soil moisture have a substantial impact on surface fluxes, as depicted by the ensemble of nine land models in ALMIP (Figure 2). Daily fluxes of latent (sensible) heat fluxes within the Mali wet feature are up to $100 \mathrm{~W} \mathrm{~m}^{-2}$ higher (lower) than adjacent dry regions. Along the flight track indicated in Figure 1(d), Taylor et al. (2007) showed that the PBL temperature was significantly correlated with the land surface temperature on wavelengths as low as $5 \mathrm{~km}$, and furthermore, found a clear correlation between surface-induced temperature gradients and the lowlevel winds. This observational result was consistent with theory (Baldi et al., 2008), and answered one of the key questions prior to AMMA. Figure 3 presents the PBL variables along the aircraft track from the observations, accompanied by output from a numerical model using alternative surface initialisations (Bastin et al., manuscript in preparation). The 'DRY' simulation was initialised using soil moisture similar to that shown in Figure 1(c) (i.e. without the Malian wet feature north of $15.5^{\circ} \mathrm{N}$ ), whereas the 'WET' simulation used data from ALMIP (Figure 1(b)). The runs demonstrate the impact of the soil moisture on the PBL temperature gradients and winds. For example, local minima in wind speed in WET (marked ' $\mathrm{X}$ ') are induced by local reversals in the temperature gradient. However, the more realistic WET simulation cannot capture the finer scale variations evident in the observations, and furthermore, neither simulation can reproduce the observed humidity.

There were also important developments in our understanding of how mesoscale soil moisture patterns influence subsequent storms. Analysis of satellite data from hundreds of storms revealed an increase of 33\% in afternoon cloud cover over dry soils compared to nearby wetter areas; a negative feedback (Taylor and Ellis, 2006). Such a result can only be explained in terms of variability in surface fluxes as both wet and dry soils were subjected to the same largescale conditions. An observational case study from an aircraft flight close to a rapidly developing MCS shed new light on this result (Taylor et al., 2010). The first cells developed along a sharp soil moisture gradient before expanding over the dry area. This suggested an important role for the surface-induced circulations discussed earlier in providing a favourable environment for convective initiation, alongside other mechanisms such as orographic forcing and cold pools. Further evidence showing the impact of surfaceinduced circulations on storm development came from numerical simulations (Gaertner et al., 2010; Gantner and Kalthoff, 2010), observations from forest-crop transitions (Garcia-Carreras et al., 2010) and satellite cloud data around the Mali wetlands (Taylor, 2010). 


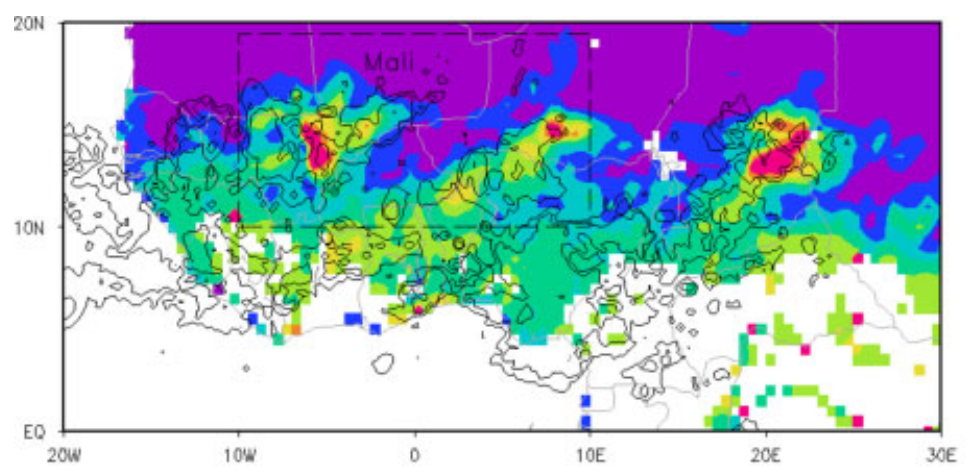

(a)
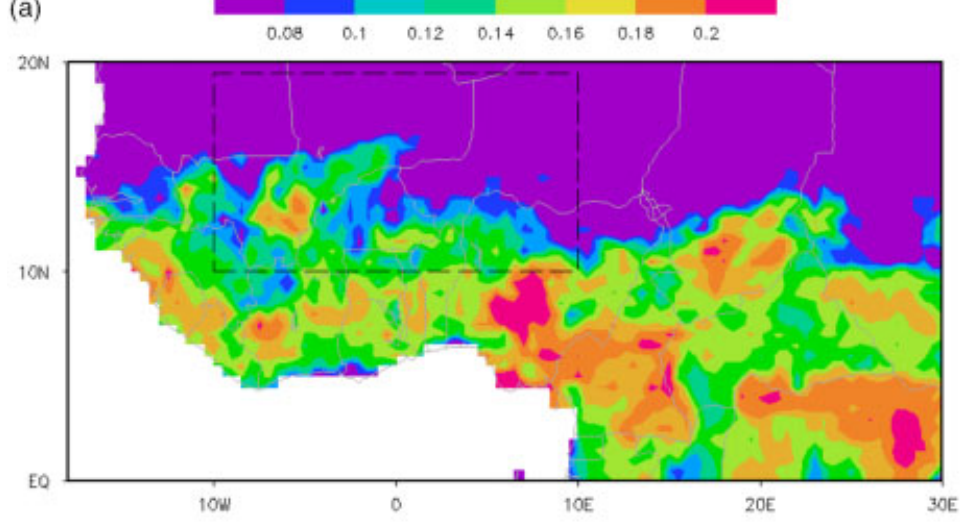

(b)

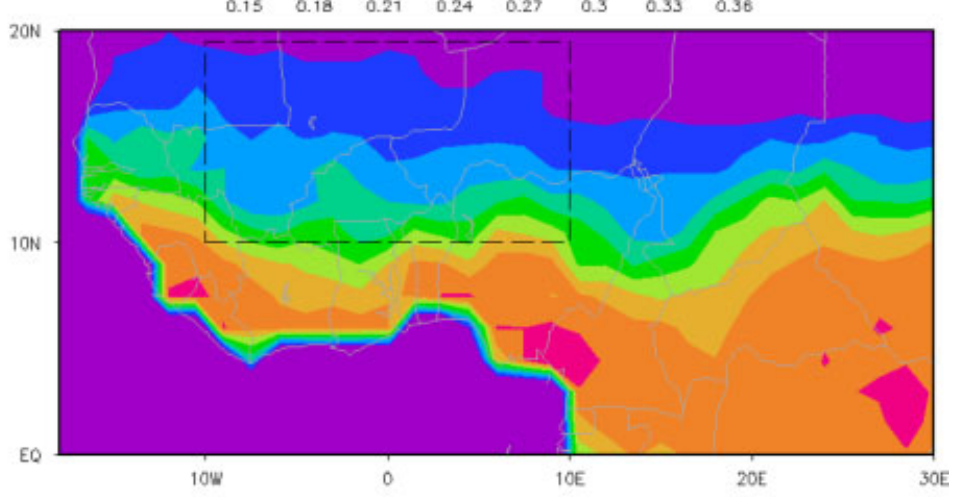

(c)
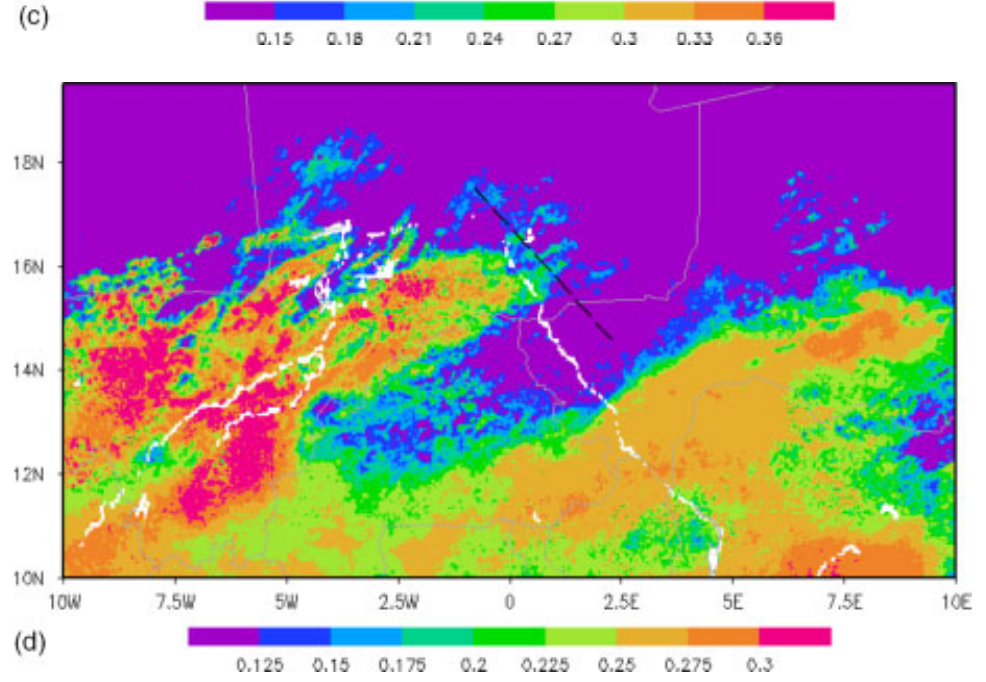

Figure I. Upper-soil moisture $\left(\mathrm{m}^{3} \mathrm{~m}^{-3}\right)$ on I August 2006 from (a) the AMSR-E satellite $(0-\mathrm{I} \mathrm{cm})$, (b) an offline simulation of a land surface model forced by ALMIP data $(0-10 \mathrm{~cm})$, (c) ERA-Interim reanalysis $(0-5 \mathrm{~cm})$ and $(\mathrm{d})$ the offline model in (b) assimilating land surface temperature data at $3-\mathrm{km}$ resolution. Total rainfall for the period 31 July to I August is shown by 10 and $30 \mathrm{~mm}$ isohyets in (a). The sub-domain of the high-resolution simulation is marked in (a), (b) and (c), and the aircraft track denoted by a dashed line in (d). 

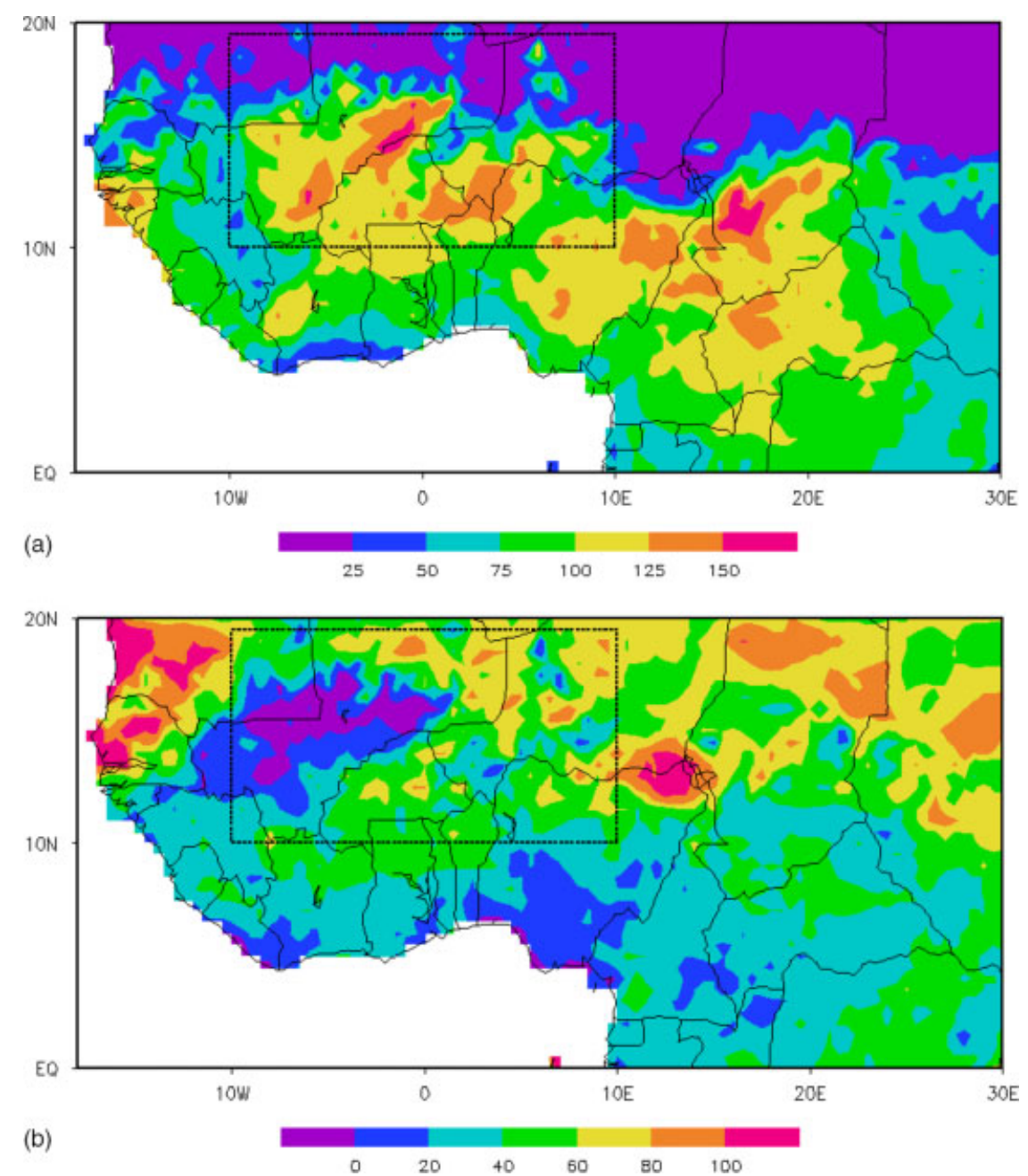

Figure 2. Latent (a) and sensible (b) heat fluxes $\left(\mathrm{W} \mathrm{m}^{-2}\right)$ on I August 2006 averaged over nine models using ALMIP forcing.

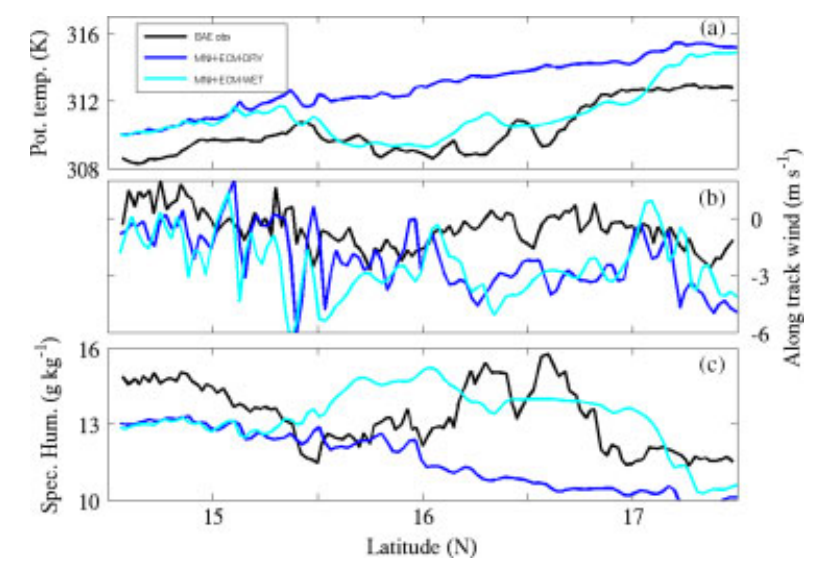

Figure 3. Aircraft observations (black) of PBL potential temperature ( $\mathrm{K}$; top), wind component $\left(\mathrm{m} \mathrm{s}^{-1}\right.$; middle), and specific humidity $\left(\mathrm{g} \mathrm{kg}^{-1}\right.$; bottom) along the track shown in Figure I(d) on I August 2006. The dark and light blue lines show these variables in numerical simulations initialised using soil moisture from European Centre for Medium Range Weather Forecasting (ECMWF) (dark blue) and ALMIP (light blue) simulations.

Once storms are initiated, our research suggests that various processes may govern the strength, and even the sign, of feedbacks between soil moisture and individual MCS. There is evidence that mature MCS with well-developed gust fronts can intensify over wet soils due to increased Convective Available Potential Energy (Gantner and Kalthoff, 2010; Taylor et al., 2010). However, this positive feedback may reverse depending on the phase of the diurnal cycle, the convective inhibition and synoptic state, and the scale and orientation of the wet patch relative to the large-scale flow (Gaertner et al., 2010).

The storm-scale feedbacks discussed here are of course embedded within synoptic disturbances. Within AMMA, Parker (2008) built on earlier work (Taylor et al., 2005) to develop a simple dynamical model of coupling between African Easterly Waves (AEWs) and soil moisture. He illustrated how soil moisture evolution can be a dynamically active part of propagating synoptic disturbances. During the AMMA aircraft campaign, one AEW event in particular - the short-lived case of 26-28 July 2006 - exhibited a notable soil moisture anomaly on the synoptic scale (Bain, 2008). Numerical modelling revealed some significant influences of the surface on the AEW, including a meridional shift and reduction in the intensity of the African Easterly Jet (AEJ) when 
Table I. Key processes of land-atmosphere coupling on different time and space scales.

\begin{tabular}{|c|c|c|c|c|}
\hline Scale & Hours - I day & Several days & Intraseasonal & Seasonal-interannual \\
\hline Plot (e.g. single raingauge) & $\begin{array}{l}\text { Diurnal cycle of PBL } \\
\text { growth driven by } \\
\text { surface heating } \\
\text { (Kohler et al., 2010) }\end{array}$ & $\begin{array}{l}\text { Surface-PBL response } \\
\text { to rain event (Kohler } \\
\text { et al., 2010) }\end{array}$ & $\begin{array}{l}\text { Impact of vegetation } \\
\text { on surface } \\
\text { thermodynamics } \\
\text { (Guichard et al., 2009) }\end{array}$ & $\begin{array}{l}\text { Land memory (Douville } \\
\text { et al., 2007; Philippon et } \\
\text { al., 2007) }\end{array}$ \\
\hline Mesoscale $(5-1000$ km) & $\begin{array}{l}\text { Surface-induced PBL } \\
\text { gradients and daytime } \\
\text { circulations (Taylor et } \\
\text { al., 2007; Baldi et al., } \\
\text { 2008). Impact of soil } \\
\text { moisture on storms } \\
\text { (Taylor and Ellis, } \\
\text { 2006; Gaertner et al., } \\
\text { 20।0; Gantner and } \\
\text { Kalthoff, 20I0; Taylor } \\
\text { et al., 20I0) }\end{array}$ & $\begin{array}{l}\text { Positive feedbacks at } \\
\text { convective scales } \\
\text { within MCS (Clark et } \\
\text { al., 2004; Taylor and } \\
\text { Lebel, 1998), negative } \\
\text { feedbacks associated } \\
\text { with initiating } \\
\text { convection (Taylor } \\
\text { and Ellis, 2006) }\end{array}$ & $\begin{array}{l}\text { Impact of longer-lived } \\
\text { surface features } \\
\text { (vegetation, wetlands) } \\
\text { on storms } \\
\text { (Garcia-Carreras et } \\
\text { al., 20I0; Taylor, } \\
2010 \text { ) }\end{array}$ & Unknown \\
\hline Synoptic - continental (>500 km) & $\begin{array}{l}\text { Sahelian heat low } \\
\text { anomalies intensify } \\
\text { overnight (Taylor et } \\
\text { al., 2005). Diurnal } \\
\text { cycle of monsoon and } \\
\text { Saharan heating } \\
\text { (Parker et al., 2005) }\end{array}$ & $\begin{array}{l}\text { Soil moisture } \\
\text { feedback on wave } \\
\text { dynamics (Parker, } \\
\text { 2008) }\end{array}$ & $\begin{array}{l}\text { Intraseasonal patterns } \\
\text { of surface heating } \\
\text { linked to rainfall } \\
\text { variability (Taylor, } \\
\text { 2008; Dominguez et } \\
\text { al., 20I0; Flaounas et } \\
\text { al., 20I0; Lavender et } \\
\text { al., 20I0) }\end{array}$ & $\begin{array}{l}\text { Soil moisture memory } \\
\text { (Eltahir and Gong, 1996; } \\
\text { Philippon and Fontaine, } \\
\text { 2002; Douville et al., } \\
\text { 2007;), interannual } \\
\text { vegetation feedbacks } \\
\text { (Charney, 1975; Zeng et } \\
\text { al., 1999) }\end{array}$ \\
\hline
\end{tabular}

the soil had dried: it appears that over a drier soil, the deeper boundary layer convection retards the AEJ. In turn, it is likely that this change in the AEJ would retard the propagation of individual MCSs.

\section{Feedbacks on intraseasonal to interannual time scales}

A major topic of interest across AMMA was the intraseasonal variability in rainfall (Janicot et al., 2011). Rainfall fluctuations on periods $\sim 15$ days in the Sahel induce a coherent, large-scale response of sensible heat flux from the land due to soil moisture (Taylor, 2008) and insolation (Lavender et al., 2010). Within a propagating AEW, or an intraseasonal synoptic wave, the land induces anomalous heat low type circulations in the northern Sahel which favour the westward propagation of the wave's envelope of rainfall, as observed. The sensitivity of this mode of variability to surface albedo (Flaounas et al., 2010) and the land surface parameterisation (Dominguez et al., 2010) was also tested. Whilst many aspects of the regional simulations were rather sensitive to the land, the timing of the active-break cycles was determined by the atmospheric lateral boundary conditions.

Although the surface memory of each individual storm is short (a few days), the root zone soil moisture, and critically, the vegetation state, depends on an integration of the water balance over much longer periods. A key question therefore is to assess how much of that information is carried over from one season to the next. Using Normalised Difference Vegetation Index (NDVI) data, Philippon et al. (2007) found evidence of an interannual land memory in the grasslands of Sahel. They found a significant increase during June in the correlation of NDVI with maximum NDVI recorded the previous year. The observations suggest a beneficial effect of high productivity in the previous year on the first flush of vegetation when the first rains fall some 9 months later. Although the mechanism remains unclear, it appears unlikely to operate directly via a memory of soil moisture in the shallow root zone of the grasses. That point was illustrated in a General Circulation Model (GCM) study (Douville et al., 2007) which depicted a strong soil moisture memory effect on the monsoon at the end of the wet season, but no evidence of similar processes operating on the interannual time scale.

\section{Perspectives on feedbacks and predictability}

Through the research in AMMA, we have a much clearer understanding of the dominant land-atmosphere feedback processes operating at different time and space scales (Table I). In particular, it is now clear that transient soil moisture patterns induce dynamic and thermodynamic responses in the PBL on length scales of ten to several thousand kilometres. These processes influence both the lifecycle of individual storms at the mesoscale, and the dynamics of the monsoon circulation, and hence the advection of moisture into the region.

Questions remain concerning the influence of the land on mature MCS, where feedbacks could have a notable impact on seasonal rainfall totals. Notwithstanding this, we are close to making practical use of the knowledge gained in AMMA, both in terms 
of bench forecasting (e.g. the use of remote sensing of soil moisture to better predict MCS and AEWs), and in longer term numerical forecasting, where the slow evolution of root zone soil moisture and vegetation relative to the atmosphere may provide additional predictability. Even with the knowledge of soil moisture gained from existing satellites, where quantitative estimates of surface state are far from ideal (Kergoat et al., 2011), we can see an important atmospheric response from case studies and statistical studies. The availability of improved estimates of soil moisture from the new Soil Moisture and Ocean Salinity (SMOS) satellite therefore holds much potential. Similarly, Figure 1 illustrates the potential benefits for short-term forecasts by running land models offline, forced by the best available (ALMIP) observations, to initialise soil moisture. Although we have shown that models produce realistic atmospheric responses to surface soil moisture contrasts in specific test cases, the representation of water vapour remains a big issue (Figure 3(c)), and it is unclear if these models are able to reproduce the full complexity of the feedback. An important result in this context is the low impact of improved soil moisture initialisation (from ALMIP) on 48-h rainfall totals predicted by the ECMWF model (Agusti-Panareda et al., 2010). That study implied that other processes (e.g. cloud, aerosol, moisture divergence) are primarily responsible for the dry bias in the ECMWF model.

On longer time scales, we have limited confidence in the ability of our models to represent the evolution of surface properties over the seasons, and respond correctly to rainfall events. Although global climate models suggest a dominant influence of tropical oceans on West African Monsoon (WAM) variability at interannual to multidecadal timescales, they lack sufficiently accurate descriptions of ecosystem and groundwater dynamics (if they represent these processes at all) to evaluate the land contribution. More difficult still is our ability to simulate with large-scale coupled models the surface-atmosphere feedbacks given the inherent problems with the representation of the atmosphere (notably precipitation) and the impact of rainfall and radiation biases on the land surface fluxes and stores. Within AMMA, techniques are being developed using cloud resolving models to evaluate the representation of feedbacks within coarse scale models.

This calls for a more systematic analysis with a number of models of the impact of improved soil moisture descriptions on atmospheric processes. Such a coordinated experiment would better identify the conditions and processes for which models diverge. This will offer guidance for revisiting AMMA observations and completing the database with results from more targeted field campaigns.

\section{Acknowledgement}

The support of the AMMA project is gratefully acknowledged (see http://onlinelibrary.wiley.com/doi/10.1002/asl.331/full for full acknowledgement).

\section{References}

Agusti-Panareda A, Balsamo G, Beljaars A. 2010. Impact of improved soil moisture on the ECMWF precipitation forecast in West Africa. Geophysical Research Letters 37: L20808. DOI: 10.1029/ 2010 GL044748.

Bain CL. 2008. Interactions Between the Land Surface and the Atmosphere Over West Africa. Thesis (Ph.D), 160 pages. University of Leeds: Leeds.

Baldi M, Dalu GA, Pielke RA. 2008. Vertical velocities and available potential energy generated by landscape variability - Theory. Journal of Applied Meteorology and Climatology 47: 397-410. DOI: 10.1175/2007jamc1539.1.

Boone A, de Rosnay P, Balsamo G, Beljaars A, Chopin F, Decharme B, Delire C, Ducharne A, Gascoin S, Guichard F, Gusev Y, Harris PP, Jarlan L, Kergoat L, Mougin E, Nasanova O, Norgaard A, d'Orgeval T, Ottle C, Poccard-Leclercq I, Polcher J, Sandholt I, Saux-Picart S, Taylor CM, Xue Y. 2009. The AMMA Land Surface Model Intercomparison Project (ALMIP). Bulletin of the American Meteorological Society 90(12): 1865-1880.

Charney JG. 1975. Dynamics of deserts and drought in the Sahel. Quarterly Journal of the Royal Meteorological Society 101: 193-202.

Clark DB, Taylor CM, Thorpe AJ. 2004. Feedback between the land surface and rainfall at convective length scales. Journal of Hydrometerology 5: 625-639.

Dominguez M, Gaertner MA, de Rosnay P, Losado T. 2010. A regional climate model simulation over West Africa: parameterization tests and analysis of land surface fields. Climate Dynamics 35(1): 249-265.

Douville H, Conil S, Tyteca S, Voldoire A. 2007. Soil moisture memory and West African monsoon predictability: artefact or reality? Climate Dynamics 28: 723-742. DOI: 10.1007/s00382-0060207-8.

Eltahir EAB, Gong CL. 1996. Dynamics of wet and dry years in West Africa. Journal of Climate 9: 1030-1042.

Flaounas E, Bastin S, Janicot S. 2010. Evaluation of the impact of Albedo, Orography, SST and Large scale Conditions on the 2006 West African Monsoon Onset. Climate Dynamics (submitted).

Fontaine B, Philippon N, Camberlin P. 1999. An improvement of June-September rainfall forecasting in the Sahel based upon region April-May moist static energy content (1968-1997). Geophysical Research Letters 26: 2041-2044.

Gaertner MA, Dominguez M, Garvert M. 2010. A modelling case study of soil moisture-atmosphere coupling. Quarterly Journal of the Royal Meteorological Society 136(S1): 483-495.

Gantner L, Kalthoff N. 2010. Sensitivity of a modelled life cycle of a mesoscale convective system to soil conditions over West Africa. Quarterly Journal of the Royal Meteorological Society 137(S1): 471-482.

Garcia-Carreras L, Parker DJ, Taylor CM, Reeves CE, Murphy JG. 2010. The impact of mesoscale vegetation heterogeneities on the dynamical and thermodynamical properties of the planetary boundary layer. Journal of Geophysical Research-Atmospheres 115: D03102. DOI: 10.1029/2009JD012811.

Guichard F, Kergoat L, Mougin E, Timouk F, Baup F, Hiernaux P, Lavenu F. 2009. Surface thermodynamics and radiative budget in the Sahelian Gourma: Seasonal and diurnal cycles. Journal of Hydrology 375: 161-177. DOI: 10.1016/j.jhydrol.2008.09.007.

Janicot S, Caniaux G, Chauvin F, de Coetlegon G, Fontaine B, Hall N, Kiladis GN, Lafore J-P, Lavaysse C, Lavender SL, Leroux S, Marteau R, Mounier F, Philippon N, Roehrig R, Sultan B, Taylor CM. 2011. Intraseasonal variability of the West African monsoon. Atmospheric Science Letters 12: 58-66, DOI: 10.1002/asl.280.

Kergoat L, Grippa M, Baille A, Eymard L, Lacaze R, Mougin E, Ottle C, Pellarin T, Roujean JL, de Rosnay P, Sandholt I, Taylor CM, Zribi M. 2011. Remote sensing of the land surface during the African Monsoon Multidisciplinary Analysis (AMMA). Atmospheric Science Letters 12: 129-134, DOI: 10.1002/asl.325.

Kohler M, Kalthoff N, Kottmeier C. 2010. The impact of soil moisture modifications on CBL characteristics in West Africa: A case 
study from the AMMA campaign. Quarterly Journal of the Royal Meteorological Society 136(S1): 442-455.

Koster RD, Guo ZC, Dirmeyer PA, Bonan G, Chan E, Cox P, Davies H, Gordon CT, Kanae S, Kowalczyk E, Lawrence D, Liu P, Lu CH, Malyshev S, McAvaney B, Mitchell K, Mocko D, Oki T, Oleson KW, Pitman A, Sud YC, Taylor CM, Verseghy D, Vasic R, Xue YK, Yamada T. 2006. GLACE: The Global Land-Atmosphere Coupling Experiment. Part I. Overview. Journal of Hydrometerology 7: 590-610.

Lavender SL, Taylor CM, Matthews AJ. 2010. Coupled LandAtmosphere Intraseasonal Variability of the West African Monsoon in a GCM. Journal of Climate 23: 5557-5571. DOI:10.1175/ 2010JCLI3419.1.

Parker DJ. 2008. A simple model of coupled synoptic waves in the land surface and atmosphere of the northern Sahel. Quarterly Journal of the Royal Meteorological Society 134: 2173-2184. DOI 10.1002/qj.343.

Parker DJ, Burton RR, Diongue-Niang A, Ellis RJ, Felton M, Taylor CM, Thorncroft CD, Bessemoulin P, Tompkins AM. 2005. The diurnal cycle of the West African monsoon circulation. Quarterly Journal of the Royal Meteorological Society 131: $2839-2860$.

Philippon N, Fontaine B. 2002. The relationship between the Sahelian and previous 2 nd Guinean rainy seasons: a monsoon regulation by soil wetness? Annales Geophysicae 20: 575-582.

Philippon N, Jarlan L, Martiny N, Camberlin P, Mougin E. 2007. Characterization of the interannual and intraseasonal variability of West African vegetation between 1982 and 2002 by means of NOAA AVHRR NDVI data. Journal of Climate 20: 1202-1218. DOI: 10.1175/jcli4067.1.

Schwendike J, Kalthoff N, Kohler M. 2010. The impact of mesoscale convective systems on the surface and boundary-layer structure in West Africa: Case-studies from the AMMA campaign 2006. Quarterly Journal of the Royal Meteorological Society 136 : 566-582. DOI: 10.1002/qj.599.

Seguis L, Boulain N, Cappelaere B, Cohard JM, Favreau G, S Galle, Guyot A, Hiernaux P, Mougin E, Peugeot C, Ramier D, Seghieri J,
Timouk F, Demarez V, Demarty J, Descroix L, Descloitres M, Grippa M, Guichard F, Kamagaté BS, Kergoat L, Lebel T, Le Dantec V, Le Lay M, Massuel S, Trichon V. 2011. Contrasted land surface processes along a West African meridional rainfall gradient. Atmospheric Science Letters 12: 31-37, DOI: 10.1002/ asl.327.

Taylor CM. 2008. Intraseasonal land-atmosphere coupling in the West African monsoon. Journal of Climate 21: 6636-6648.

Taylor CM. 2010. Feedbacks on convection from an African wetland. Geophysical Research Letters 37: L05406.

Taylor CM, Ellis RJ. 2006. Satellite detection of soil moisture impacts on convection at the mesoscale. Geophysical Research Letters 33: L03404.

Taylor CM, Ellis RJ, Parker DJ, Burton RR, Thorncroft CD. 2003. Linking boundary-layer variability with convection: a case-study from JET2000. Quarterly Journal of the Royal Meteorological Society 129: 2233-2253.

Taylor CM, Harris PP, Parker DJ. 2010. Impact of soil moisture on the development of a Sahelian mesoscale convective system: a case Study from the AMMA special observing period. Quarterly Journal of the Royal Meteorological Society 136: 456-470.

Taylor CM, Lebel T. 1998. Observational evidence of persistent convective-scale rainfall patterns. Monthly Weather Review 126: 1597-1607.

Taylor CM, Parker DJ, Harris PP. 2007. An observational case study of mesoscale atmospheric circulations induced by soil moisture. Geophysical Research Letters 34: L15801.

Taylor CM, Parker DJ, Lloyd CR, Thorncroft CD. 2005. Observations of synoptic scale land surface variability and its coupling with the atmosphere. Quarterly Journal of the Royal Meteorological Society 131: 913-938.

Xue Y, Shukla J. 1993. The influence of land-surface properties on Sahel climate. 1. Desertification. Journal of Climate 6: $2232-2245$.

Zeng N, Neelin JD, Lau KM, Tucker CJ. 1999. Enhancement of interdecadal climate variability in the Sahel by vegetation interaction. Science 286: 1537-1540. 